\title{
BEN JELLOUN'S POINT OF VIEW ON RACISM IN THE ESSAY LE RACISME EXPLIQUEÉ À MA FILLE
}

\author{
Annisa Nitya Pradivta ${ }^{1, *}$, Diah Kartini Lasman ${ }^{2}$ \\ ${ }^{1}$ French literature, Faculty of Humanity, University of Indonesia, Depok, West Java 16424, Indonesia \\ ${ }^{2}$ French literature, Faculty of Humanity, University of Indonesia, Depok, West Java 16424, Indonesia
}

\section{A RTICLE INFO}

Keywords:

Isotopes

Moroccan literature

Racism

Socio-cultural

Tahar Ben Jelloun

Article History:

Received: 30/03/2021

Accepted: 25/05/2021

Available Online:

$31 / 05 / 2021$

\begin{abstract}
A B S T R A C T
Moroccan literature has been growing since the 1950s, when Morocco was still under French occupation. The big themes that commonly appear in Moroccan literature are the issues of colonialism and racism. One Moroccan writer whose work speaks a lot about racism is Tahar Ben Jelloun. This article aims to analyze one of Ben Jelloun's works entitled Le Racisme expliquée à ma fille. The essay discusses a father and his 10-year-old daughter about racism and what makes people became a racist. In the essay, some words are in bold, and these words are mostly phenomena or social events related to the dark history of world civilization due to racism. This study used a qualitative method by using Genette's focalization theory and opposition theory by Greimas markers. The analysis results show that the concept of racism in this essay is conveyed through the father's focalization even though the essay's form is a question and answer between the father and daughter. The selection of forms of dialogue with father and daughter figures can be seen as a narrative strategy to convey the implicit meaning to combat racism. Anti-racism education in the family is Tahar Ben Jelloun's reflection on solutions to racism in the world.
\end{abstract}

2442-305X / (C) 2021 The Authors, this is open access article under the (CC-BY-NC) license (https://creativecommons.org/licenses/by-nc/4.0/), DOI: 10.19105/ojbs.v15i1.4512

\footnotetext{
$\bar{*}$ Corresponding Author:

Email address: annisapradivta1@gmail.com (A. N. Pradivta)
}

\section{A. Introduction}

Francophone literature is a literary work that uses French and has appeared in many countries of the former French colonies. The countries of the former French colonies are scattered worldwide, one of which is Morocco. France colonized Morocco from 1912 to 1956. The linguistic legacy, the French language, is preserved because it is considered an important language. French is considered superior to Arabic and Berber (the native language of North Africa). French is also used in the education system as a second primary language.

Francophone literature began to emerge in 1930 in Algeria and then 
developed in Morocco and Tunisia. Their works at that time were heavily influenced by the French, who dominated these countries. Since 1950, Maghrebian authors started getting many recognitions. Many people started to read francophone literature, and Magrebian authors began to be known internationally. Maghrebian authors also began to get many attentions, and they also began to get awarded, such as Kateb Yacine for his works, L'Ouvre en Fragments, who awarded the Prix National de Lettres in 1986, and also Tahar Ben Jelloun, who get awarded the Prix Goncourt in 1987 for his works, La Nuit Sacré. ${ }^{1}$

The first generation of Maghrebian authors gets much attention from the critics and the public because it shows the lives of the people who live in northern Africa, Arab, and the Berberian. European people saw Maghrebian authors' work often in post-colonial themes such as anger and grief over the exploitation, colonial injustice, misery, humiliation, and the rebellion against ancestral authority and boundaries. ${ }^{2}$

One of the Maghrebian authors that is famous is Tahar Ben Jelloun. Tahar Ben Jelloun is one of the most successful francophone authors until these days. Ben Jelloun's victory in the Prix Goncourt in 1987 for his work entitled La Nuit Sacrée opened many people's eyes to Ben

\footnotetext{
${ }^{1}$ Jean Déjeux, Littérature Maghrébine de Langue Française: Introduction Générale et Auteurs (Sherbrooke: Éditions Naaman, 1980), 1-7.

2 Najib Redouane, "La Littérature Maghrébine d'Expression Française au Carrefour des Cultures et des Langues," The French Review 72, no. 1 (1998): 81-90, https://www.jstor.org/stable/399097.
}

Jelloun's work as well as the works of Maghrebian authors in general. Ben Jelloun consistently writes about Moroccan culture in an exotic way but also voice his critique of the West such as Hospitalité française in 1984, L'enfant de sable in 1985, La Nuit Sacrée in 1987, Les yeux baissés in 1991, Le Racisme expliqué à ma fille in 1997, Partir in 2006 , and Au pays in 2009. ${ }^{3}$

Ben Jelloun gained attention because he often appeared in French media and talking about the injustice and the suffering of the North African people in Europe. This is an important dimension of some of Ben Jelloun's works. ${ }^{4}$ One of his works that raises the condition of African people in Europe is Le Racisme Expliquée à Ma Fille. It is an essay that tells about the meaning of racism and the concepts that surround it. This essay is written in the form of dialogues between a father and his daughter discussing racism. It is published by Seuil in 1997 .

This essay is chosen because it has been translated into many languages. It also talks about the topic that is commonly known worldwide, which is racism. It used simple but deep language to transfer the message to the readers. That is why this essay is chosen so that everyone can know the meaning of this essay.

Although there have been many pieces of research about Tahar Ben Jelloun's works, there is no specific

\footnotetext{
3 Anouar El Younssi, "An Exoticized World Literature: Ben Jelloun at the Two Shores of the Mediterranean," Alif: Journal of Comparative Poetics 34 (2014): 225-50.

${ }^{4}$ Younssi, 225.
} 
research about this essay. The first research about Tahar Ben Jelloun's work belongs to Oom Rohmah Syamsuddin from Universitas Indonesia. ${ }^{5}$ This research was conducted in 2014 and discussed many problems of immigrants in France. This work also presents the socio-cultural conditions in Frans in the 1970s and the post-independence Maghreb. This research stated that the French "negative" view of the Maghreb was based on Chauvinism, excessive pride in the country. Both novels showed the conflicts, especially the inner conflict, social, and especially cultural conflict related to one another. I pick this research because it discusses the same author, Tahar Ben Jelloun.

The second one is belong to Yoga Eka Wirawan entitled Konstruksi Identitas Budaya Tokoh dalam Cerpen Le Père Noël N'est Pas Musulman Karya Tahar Ben Jelloun. ${ }^{6}$ Yoga stated that there is a difference in the construction of identity between Mohamed and his children. These differences cause many conflicts between them. This happened because Mohamed's children constructed their identity as a French citizen. Mohamed didn't want to celebrate Christmas because of his perception of God. He considered that Christmas celebrations

5 Oom Rohmah Syamsuddin, "Hibriditas dalam Permasalahan Imigran Maghribi di Prancis dan Penyajiannya dalam Les Raisins de Galère dan Les Yeux Baissès Karya Tahar Ben Jelloun" (Unpublished Doctoral Dissertation, Universitas Indonesia, 2014).

${ }^{6}$ Yoga Eka Wirawan, "Konstruksi Identitas Budaya Tokoh Dalam Cerpen Le Père Noël N'est Pas Musulman Karya Tahar Ben Jelloun" (Minithesis, Depok, Universitas Indonesia, 2018). were equivalent to Eid al-Adha, even though it's only an event to share gifts in his children's minds. This research is chosen because it has the same theme as this essay, which is racism.

The third research is written by Ahmad Syarief entitled Rasisme Terhadap Anak Muda dalam Lagu Ma Couleur sung by a rapper named Booba. ${ }^{7}$ It discussed the discrimination based on skin color in France and that the identity of the young Nigerian can not be separated from criminality, violence, and oriented to richness and money. But they respect the women and the mom figure in their life, also they have the high responsibility even though they did not think about the education. Both of these researches talk about racism in France. This research will increase knowledge about racism in France and Ben Jelloun's view on how to overcome it.

Ben Jelloun explains in the foreword of this Essay that this Essay was made when he and his daughter saw a banner during the massive demonstration on February 22, 1997 against the Debré Law on foreigners' entry and residence permit in France. On his return home, she asked her dad about the meaning of racism, and that's when they start talking about racism and the concepts surrounding it.

In the essay Le Racisme Expliqué à Ma Fille, there are some bold words and many explicit questions about racism. Therefore, the problem that we will discuss is Tahar Ben Jelloun's View of

\footnotetext{
${ }^{7}$ Ahmad Syarief, "Rasisme Terhadap Anak Muda Dalam Lagu Ma Couleur" (Minithesis, Depok, Universitas Indonesia, 2014).
} 
Racism in the Essay Le Racisme Expliqué à Ma Fille. This research aims to explain racism in the essay and reveal Ben Jelloun's concept on how to change someone's mind about racism.

\section{B. Method}

This research used qualitative research with non-numerical research data. Based on that background, this research used two theories; those were Gerard Gennette's theory about focalization to explain the narrative strategy used in the essay, ${ }^{8}$ as well as isotopy theory by A. J. Greimas ${ }^{9}$ to interpret Ben Jelloun's keywords about racism in the essay.

The focalization theory that will be used is the theory proposed by Gerard Genette. Focalization, according to Genette, is differentiated between mood and voice. The focalization is in mood level because it is based on the perspective of the character. In this essay, the dialogue is between a father and a daughter using clear and straightforward language. Genette divides narrative focalization techniques into three categories. The first one is zero focalization, where the narrator has an allknowing nature. The second is extern focalization, where the narrator becomes an impartial, objective observer. The third is internal focalization, where the narrator only knows everything and sees what a character knows and sees. This essay has internal focalization because the narrator has all-knowing knowledge and is centered on one character's opinion.

Greimas propose the theory to talk about the isotope. Furthermore, Greimas stated that humans construct and recognize meanings based on the opposition between markers.

\section{Results}

\section{Racism according to Tahar Ben Jelloun}

The first-word field that is subjected to racism case is segregation. The word 'segregation' based on Larousse Online Dictionary means action de mettre à part quelqu'un, un groupe (Action of setting apart someone, a group). The words that include in this field are discrimination (discrimination), étranger (foreigner), refus (refuse), rejet (reject), and ghetto (ghetto). The word 'discrimination' (discrimination) indicated an intentional separation between one group and another. People who commit acts of discrimination are consciously separated into groups who were considered inferior to their group because they feel that the group does not belong to their community.

\footnotetext{
${ }^{8}$ Genette Gerard, An Essay in Method (New York: Cornell University, 1980), 161-212.

9 A. J. Greimas as quoted by Robert Stam, New Vocabularies in Film Semiotics (London: Routledge, 1992), 77.
} 
Table 1. Isotopes Ségrégation

\begin{tabular}{lccc}
\hline $\begin{array}{l}\text { Words that include in the } \\
\text { isotope "Ségrégation" }\end{array}$ & \multicolumn{3}{c}{ Components of shared meaning } \\
\cline { 2 - 4 } & $\begin{array}{c}\text { Action de } \\
\text { Séparation }\end{array}$ & $\begin{array}{c}\text { Action à } \\
\text { quelqu'un }\end{array}$ & $\begin{array}{c}\text { Le groupe the } \\
\text { minorité }\end{array}$ \\
\hline Discrimination & + & + & + \\
Refus & + & + & - \\
Rejet & + & + & - \\
Ghetto & + & - & + \\
\hline
\end{tabular}

From table 1, it can be seen that the four words have the same component, which is 'Action de Séparation' (Separation Act) because they are deliberately separate a group from another group in one area. The word discrimination has a connotative meaning 'Le Groupe de Minorité' (Minority Group), because, in terms of the number of the members, the minority group is often discriminated against by the majority. Meanwhile, the word 'Refus' (refuse) and 'Rejel' (reject) do not have the component 'Le group de minorité' (minority group) because it is not necessary that the person whose existence is rejected is the minority. Then the word 'Ghetto' (Ghetto) has an obvious connection with 'Action de Séparation' (separation act) and 'Le group de minorité' (minority group) because of the intention of separating the minority group from the community. According to Ben Jelloun, racism is related to segregation, which is the intention to separate a group of people from another group because of racial differences.

Next is the word refus (refuse) and rejet (reject), which occurs when an individual or a group rejects the arrival of another group in their environment. Next, there is the word ghetto (Ghetto), which occurs when a group lives apart from a neighborhood in an area. These four words confirm Ben Jelloun's assertion that racism is closely related to a group's dislike of other groups.

The second field of meaning is colonialism (colonialism), which in the dictionary online "Larousse" means système qui préconise l'établissement et le développement de pays dépendants considérés comme sources de richesse et de puissance pour la nation colonisatrice. (a system that advocates the establishment and development of dependent countries as sources of wealth and power for the colonizing nation). The words included in this field are colonialism (colonialism), esclavage (slavery), and Apartheid (Apartheid). The word colonialism indicates an attempt by a country to rule another country. This certainly has a bad impact on the colony state because the invaders will spend the natural resources in the country while utilizing their human resources. Then there is the word esclavage (Slavery), which occurs when a person colonizes 
another individual for his benefit. time, white people discriminated against Furthermore, the word Apartheid black people because they felt they were (Apartheid) is closely related to at the top level.

colonialism, especially in Africa. At the

Table 2. Isotopes Colonization

\begin{tabular}{lccc}
\hline $\begin{array}{l}\text { Words that were included } \\
\text { in the isotope } \\
\text { "Colonization." }\end{array}$ & \multicolumn{3}{c}{ Components of shared meaning } \\
\cline { 2 - 4 } & Has a system & $\begin{array}{c}\text { Group } \\
\text { Action }\end{array}$ & $\begin{array}{c}\text { Political } \\
\text { Activities }\end{array}$ \\
\hline Colonialism & + & + & + \\
Slavery & + & - & - \\
Apartheid & + & + & + \\
\hline
\end{tabular}

From table 2 can be seen that word colonialism has a component meaning 'has a system' because, in the denotative meaning, there is the word systeme, but also has a component 'Group Action,' which means colonialism is done in groups, not individuals. Colonialism also encompassed the political realm, therefore incorporated into the component of political meaning.

The word slavery has a connotative meaning has a system. In this case, systeme is related to the hierarchy and oppression. Martasudjita declares that the slave without rights all he has is an obligation. He must serve his master at any time. A slave has no power even over his own life. He lives for his master. He must be ready to be loyal when carrying out his master's orders. ${ }^{10}$

This indicated that in a community, there are people who are considered

10 E. Martasudjita, Pelayanan yang Murah Hati (Yogyakarta: Kanisius, 2003), 40-41. inferior due to skin color. Slavery also leads to the human desire to rule over others who were considered inferior. The third is Apartheid. The word Apartheid has a component 'has a system' because it occurs in a country and lasts for many years, and is carried out in groups, between the minority and majority. The word Apartheid had a connotative meaning: 'Political Activities' because it was related to the political system in 1930 in Africa.

The third field is intolerance, which in the dictionary online Larousse means refus d'admettre l'existence d'idées, de croyances ou d'opinions différentes des siennes (refusal to admit the existence of ideas, beliefs or opinions different from one's own) the words that belong to the field of intolerance are refus (refuse), préjugés (prejudice) and Xenophobie (Xenophobia). Prejudice can occur when a person feels or thinks someone else will do him or her evil when he or she has just 
met that person. This prejudice can occur if we are new to the person. That bad prejudice will lead to acts of racism. Racism is a feeling that cannot be objectively justified. They were just scared because they didn't know the stranger. Xenophobie can occur when this prejudice is silenced and eventually becomes a hatred of strangers. Racist people will hate those who are considered strange, especially those who are not from their race. Prejudice and Xenophobies can enter into intolerance because prejudice occurs due to a person's dislike when seeing people of other races, and Xenophobie can enter into the field of intolerance Xenophobie is one of the manifestations of such prejudice.

Table 3. Isotopes Intolerance

\begin{tabular}{lcc}
\hline $\begin{array}{l}\text { Words that were included } \\
\text { in the isotope } \\
\text { "Intolerance." }\end{array}$ & \multicolumn{2}{c}{ Components of shared meanings } \\
\cline { 2 - 3 } & $\begin{array}{c}\text { Action of } \\
\text { Judging }\end{array}$ & $\begin{array}{c}\text { The way to look at } \\
\text { someone }\end{array}$ \\
\hline Prejudice & + & + \\
Xenophobie & + & + \\
Refuse & + & + \\
\hline
\end{tabular}

Table 3 explains that the words Prejudice and Xenophobie have the same components, those are Action of Judging and The Way to Look at Someone. The word préjugé has a denotative meaning, which is 'Action of Judging' because prejudice can arise from an individual's judgment of another person or other group in their environment. The word xénophobe has a connotative meaning: "Action of judging" because a person's hatred towards another arises from a bad judgment. The word also signifies a hierarchy because there are individuals who feel entitled to judge others simply because they feel superior. The word xenophobie also has a connotative meaning: 'The way to look at someone,' which means that displeasure arises from judgments initiated by this racist way of looking at people. The word refus only has a component, 'The way to look at someone,' because one would reject another person if they viewed the person differently from him. This indicates that a racist person considers a person who is different from them, especially those in the lower degree.

The fourth field is destruction (Destruction) which in the dictionary means action de détruire quelque chose ou quelqu'un, de jeter à bas (destroy something or someone, to throw down), which includes extermination (extermination) and génocide (genocide). These two words both mean the massive destruction of a group. Both terms are used to assert that racism is a social concept that can lead to the death of a community. 
Table 4. Isotopes Destruction

\begin{tabular}{lccc}
\hline $\begin{array}{l}\text { Words that were included } \\
\text { in the isotope } \\
\text { "Destruction." }\end{array}$ & \multicolumn{2}{c}{ Components of shared meanings } \\
\cline { 2 - 4 } & $\begin{array}{c}\text { Action to } \\
\text { Someone }\end{array}$ & Massacre & Crime Action \\
\hline Extermination & + & + & - \\
Genocide & + & + & + \\
\hline
\end{tabular}

In table 4 , it can be seen that the word extermination has a denotative component of massacre, meaning this word indicates that racism is an act that can annihilate a community. The word also has a denotative meaning, those are 'action to someone,' and a component of the connotative meaning 'Crime Action,' which means extermination is an active concept, not passive, and is one of the criminal acts.

The word genocide also has all three components of meaning. The word has a denotative component of action crime meaning genocide is included in criminal acts. The word genocide has the denotative meanings of 'action to someone' and 'massacre,' meaning genocide is an active action and causes many fatalities. In a connotative state, this relates to a group's desire to eliminate those who are different. Thus homogeneity is the thing to be achieved when humans are different.

The fifth field is action, which in the dictionary means fact or faculty of acting, of manifesting one's will by accomplishing something, the words that are included in this field are discrimination (discrimination), pulsion (impulse), extermination (extermination), refusal, rejection. These five words are in the state of action. This means racism is an action that can damage human life. The use of these five words also shows that racism can not only be done by one person but can also be done in the form of a group.

Table 5. Isotope Action "Action"

\begin{tabular}{lcc}
\hline $\begin{array}{l}\text { Words that were included } \\
\text { in the isotope "Action." }\end{array}$ & \multicolumn{2}{c}{ Components of shared meanings } \\
\cline { 2 - 3 } & Something that is active & Physical Activity \\
\hline Discrimination & + & - \\
Impulse & + & + \\
Refusal & + & - \\
Rejection & + & - \\
Extermination & + & + \\
\hline
\end{tabular}


From table 5 it can be seen that all the words in the field of action meaning have a component of 'Something that is active,' this indicates that racism is real and done by the dominant party. The word impulse, and extermination has a component of the meaning of 'Physical Activity' because all three words are related to the destruction or coercion of a person's physique. So, racism is an active act that has a negative impact and not something passive. In addition, these five words also indicate that racism is something real, which exists in everyday human life.
The next field is the human included in it: étranger (foreigner), bouc émissaire (scapegoat), and Xenophobie. The use of these three words and boldly printed to indicate that racism is closely related to human beings, be it women or men. The word étranger (foreigner) means a person from outside the region or a foreigner. It is these foreigners who can trigger acts of racism in the region or the country. The word Xenophobie has the same implicit meaning as the word étranger (foreigner), i.e., unknown person. Xenophobie is a form of racism, which is fear or a form of hatred against people from other countries or considered foreign.

Table 6. Isotope Humain "Human"

\begin{tabular}{lccc}
\hline $\begin{array}{l}\text { Words that were included } \\
\text { in the isotope "Human." }\end{array}$ & \multicolumn{3}{c}{ Components of shared meanings } \\
\cline { 2 - 4 } & $\begin{array}{r}\text { Someone } \\
\text { Unknown }\end{array}$ & $\begin{array}{c}\text { Group } \\
\text { Activity }\end{array}$ & $\begin{array}{c}\text { Personal } \\
\text { Activity }\end{array}$ \\
\hline Foreigner & + & - & + \\
Scapegoat & - & + & + \\
Xenophobie & + & + & + \\
\hline
\end{tabular}

Once described, there is a human isotope in the essay, as in table 6, which includes foreigner, scapegoat, and xenophobie. The words foreigner and xénophiobie both have components of 'Someone unknown' meaning because they do not know who the person is, and 'Personal Activity' because the subject is a person. Xenophobie also has a component meaning 'Group Activity' because it can be done in groups. While scapegoat has two components of meaning: 'Group Activity' and 'Personal Activity'; because the perpetrator or victim could be a group of people or an individual.

The seventh field of meaning is a person's biological factor, including genetics, melanin, blood type, and heredity. A person's biological state can be a real daughter for someone not to act racist. A person's biological state is carried from his birth until he matures and is inseparable. These four words indicate 
that the Father wants his child to understand one's outward circumstances as irrefutable. Genetics is a broad science that includes DNA, plasmids, cell reproduction, heredity, etc. Genetics is something of hereditary origin, and if a person has black parents, the child will also be black. Blood type is an irrefutable hereditary factor. It has nothing to do with race. Ben Jelloun says that people differ because of their hereditary factors, not because of their race.

Table 7. Isotope Organic "Biologis"

\begin{tabular}{lccc}
\hline $\begin{array}{l}\text { Words included in the } \\
\text { isotope 'Biologique.' }\end{array}$ & \multicolumn{3}{c}{ Components of shared meanings } \\
\cline { 2 - 4 } & $\begin{array}{c}\text { Genetically } \\
\text { Linked In }\end{array}$ & $\begin{array}{c}\text { Relation to The } \\
\text { Skin }\end{array}$ & $\begin{array}{c}\text { Relation to The } \\
\text { Genes }\end{array}$ \\
\hline Mélanin & - & + & - \\
Blood Type & + & - & + \\
Genetics & + & + & + \\
Heredity & + & + & + \\
\hline
\end{tabular}

From table 7 , we can see that the biological isotope is also emphasized in this essay. The word melanine has the denotative meaning of skin because an individual's melanin affects the color of their skin. Then blood type has the meaning of denotative genetically linked in because it relates to genes or heredity. Furthermore, the word Genetics has a component of the three-thirds of its connotative meaning because it is genetically related to heredity and can affect skin color and heredity.

A person's biological factors are affirmed using bold words. It appears that when talking about racism, Ben Jelloun returns to the word "Race" as a biological factor. It is an internal factor of a person that cannot be changed. This shows Ben Jelloun's view that racial differences should be treated as biological differences, i.e things that cannot be changed by a person, there is nothing superior and inferior, this is also stated in Article 7 of the Universal Declaration of Human Rights adopted by the United Nations, namely that everyone is equal in the eyes of the law and entitled to legal protection without any discrimination.

From the explanation above, bold words are dominated by words directly related to racism and related to sociohistoric concepts. This more prominent socio-historical concept indicates that Ben Jelloun wanted readers to understand that racism was a social construct built by a group of people. A biological factor that is also emphasized is an affirmation that a person's race is something that cannot be chosen or changed. Racism, rooted in the word race, has nothing to do with the concept of race biologically. 
This section also describes the field of meaning and isotope in the essay, namely isotope segregation, isotope intolerance, isotope colonization, isotope extermination, human isotope, isotope action, and biological isotope. The terrain of segregation means that racism originates from the separation between one group and another. The terrain of colonialism shows that racism can be done in groups and related to politics. The field of intolerance indicates that racism arises from one's view of another person or group.

This suggests that there is a person or community that feels superior to other groups of people. The terrain of extermination proves that racism can annihilate a particular racial group. The field of action proves that racism is active, not passive. The terrain of human meaning shows that racism is very closely related to human beings and the prevailing systems in a region. Biological concepts are included only a few compared to socio-historical concepts. This indicates that racism is defined as a social construct, not a biological one.

\section{Narrative Strategy: Form of} Dialogue and Focalization of Father - Daughter

The theory of focalization to be used is the theory initiated by Gerard Genette. Focalization, according to Genette, distinguishes between mood and voice. The location of the focal is the mood because it is based on the perspective of the viewing of the father and daughter. In this essay, the story is through father- daughter dialogue using straightforward and clear language.

Genette divides narrative focalization techniques into three categories. The first is focalisation zéro, the narrator has an all-knowing nature, the second is focalisation externe, the narrator becomes an impartial, objective observer, and the third is focalisation interne, i.e. the narrator is only all-knowing and sees what is known and seen from a character. Le racisme expliqué à ma fille essay has interne focalisation because the narrator has an all-knowing and opinion-centered nature of one figure. The focalization technique shows the dominance of the father's opinion on racism.

In this essay, it can be seen that the focalisator is father and daughter, with the Father being the source of information that the child asks, the father answers. In addition to father-daughter questions relating to bold words, some fatherdaughter dialogues speak explicitly about racism.

The focalisation between father and daughter can be seen clearly that it is just as much. This indicates that, in the text, the portion of the daughter and father is the same but it appears that the child concludes the father's explanation of racism. So it is actually the father's opinion that forms the opinion of his daughter, the following quote affirms this.

"Si ça touche tout le monde, je pourrais être raciste!"

"On ne naît pas raciste, on le devient. II y a une bonne et une mauvaise éducation. Tout dépend de celui qui 
éduque, que ce soit à l'école ou à la maison." $" 11$

(If it affected everyone, I could have been a racist!)

(Someone is not born to be racist, yet 'being' racist. That's between good or bad education. It all depends on those who teach, whether it's at school or home).

The quote confirms that the concept of racism is a formation of the community around where a child lives. The two excerpts below show that no child is born racist. Education becomes the main factor in shaping a child's reality. A good education will produce good thinking; otherwise, bad thinking will produce bad ideas in a child. A child who in his home is educated to be a racist person, suppose their neighbors come from different areas and have different skin colors, then the child's parents forbid the child to play with their neighbors, this can instill the mindset of the child that he should not play with different groups like his neighbors.

When a child is firstborn in the world, the first person he knows is his parents and his surroundings. Furthermore, parents will educate the child before the child enters the educational institution, namely the school. The education obtained by a child will affect the child's mindset in the future because a child will be easier to instill the concept of something than an adult. A child will also more often model what his parents do. In addition to parents, education obtained from the community

11 Tahar Ben Jelloun, Le Racisme Expliqué à ma Fille (Paris: Editions du Seuil, 2018), 3. around the child is also important in forming a child's mindset, including the school where the child receives a formal education.

"Tu crois que je pourrais devenir raciste? Le devenir, c'est possible ; tout depend de l'éducation que tu auras reçue."

(Do you believe that I can be a racist? yes, it's possible; it all depends on the education you receive.)

When the daughter asked if she might be a racist or not, her father replied, maybe. This reaffirms that education is one thing that is important to a child's future. In France, education is an obligation for a child. Since the existence of the Loi de Jules Ferry on March 28, 1882 , education is an obligation for a child from the age of three, whether they are a French citizen or a foreigner living in France. At first, education is required until 13 years old; then it changed to 14 years following the Law dated August 9, 1936. But then, since regulation no. 45-59 dated January 6, 1959, education becomes mandatory until the child is 16 years old (https://www.education.gouv.fr).

With this compulsory learning program, all children get the same right to get an education in France. That way, there should be common knowledge at the level of basic education in France. But, in the father's view in the text, the quality of education received by French children is not the same, so a child may become racist for not getting a good education.

12 Jelloun, 3-4. 
Of course, education is not only obtained at school, but also at home. Education in childhood is very important and very influential for their future. Childhood education is able to help children to develop socially and emotionally. In the sense that parents should be able to help the child have good social and emotional abilities. Children who have good social skills will get used to socializing with their surroundings without differentiating racial groups, tribes, religions, etc. They can also build good relationships with their friends. That is why it implicitly appears that the father in this essay is educating his daughter not to be racist.

There is also a quote that questions whether racism is normal because it is often found everywhere:

"Quand tu dis " commun ", tu veux dire normal?

Non. Ce n'est pas parce qu'un comportement est courant qu'il est normal"13

(Daughter: When you say "Ordinary," you mean normal?"

(Dad: No. Not that an action is considered normal, it means normal)

Racism is considered "commun" because acts of racism are common and sometimes even an individual or a group acts racist without them noticing. But even so, the act of racism is not something that is considered normal by the father. Thus, an act of racism is not a justified act and must be removed. Here Ben Jelloun's opinion is very firm and normative

\footnotetext{
13 Jelloun, 2.
}

regarding what is normal and not. From the quote, it is also implied that the actions of the majority do not mean the truth.

"Le raciste est celui qui pense que tout ce qui est trop différent de lui le menace dans sa tranquillité."14

$A$ racist person is one who thinks that everything very different from him will threaten his composure.

The quote shows the concept of racism from the focalization of the father. It shows that the concept of racism has negative connotations, according to him. Racist people will see different people as their threat. A racist will feel his group's composure disturbed when other different individuals are entering his neighborhood. They feel that the new person is a threat and can ruin the tranquility of his life.

From the exposure, it can be seen that the idea presented is an argument, and this is an essay. The chosen form of dialogue is a more interesting form than a form of description. The selection of father and daughter figures in dialogue also allows informal language to be used in the text. This makes the serious concepts that need to be explained can feel easier to digest. In addition, through the exposure of analysis before, it can be seen that, in fact, this is the voice of Ben Jelloun, who borrowed the focalization of father and daughter.

Both figures in the essay consider that racism has negative connotations. The two points of view shown in the essay show that the daughter and father agree

${ }^{14}$ Jelloun, 4. 
that racism is a negative act. The father considers that education in the family plays the most important role. Ben Jelloun also thinks that racist people are cowards. They are afraid of something they do not know. Ben Jelloun said that a racist person might learn another language or culture but that does not mean he will accept people with that culture or language.

\section{Socio-Historical Aspects that Affect Racism}

The previous section has analyzed bold words. Below will be further analyzed bold words and directly related to the socio-historical context surrounding racism. The word relates to the sociocultural aspect and relates to the historical context, such as antisémitisme, gouvernement, culture, Apartheid, colonialism, esclavage, ghetto, and genocide.

Antisemitism is a feeling of dislike, prejudice, or discrimination against Jews. ${ }^{15}$ This behavior has existed since time immemorial when Hitler tried to crush the Jews in Germany. Antisemitism, in general, can be considered as an act of racism. ${ }^{16}$ Antisemitism arises from the perception of Jews as greedy people, this perception likely developed in Europe

\footnotetext{
${ }^{15}$ Paul Johnson, A History of the Jews (New York: Harper Perennial, 1988), 133, https://www.cambridge.org/core/journals/languageteaching/article/abs/influence-of-bilingualism-onthird-language-acquisition-focus-onmultilingualism/EF22C832FD4EFEFD835DB6B11D B5CDD4.

16 Julie Nathan, "Report on Antisemitism in Australia 2019" (Edgecliff: Executive Council of Australian Jewry, 2019), 10.
}

during the Middle Ages because most of the money lending efforts were managed by Jews.

A country that indirectly discriminates against residents of other countries will cause its indigenous people to become racist. The state must think about all of its people without exception. However, a country often makes regulations that indirectly isolate or demean people from other countries. For example, in France, this country has long had immigrants, especially from Africa, but these immigrants were discriminated against and ostracized by native French. This is an example that bad governance will produce bad people. The government certainly holds the highest role in state power. The government is the people who should be able to do justice to all their people without exception.

The diversity of cultures in the world often makes a group of people feel superior to other cultures considered inferior. This can make someone unconsciously racist. For example, white people have always considered their culture to be superior to that of black people until the idea emerged that white people should teach black people to be more civilized. With that in mind, white people assume that black people are not as cultured as they are and that black people are at the lowest cultural hierarchy.

The socio-cultural concepts refer to that racism is negative and fatal. Racist people think that race is the greatest compared to other races in the world, so that it takes actions that lead to the destruction of a community. Those who 
are constructed as superior races often commit acts of racism against the lesser perceived class. Racism occurs in a heterogeneous society because often cultural differences make more minority groups discriminated against.

Furthermore, several socio-cultural concepts are closely related to the extermination of a community, such as culture, genocide, ghetto, esclavage, Apartheid, and colonialism. A more superior group would feel very powerful and could arbitrarily oppress a more inferior group in a region. They often think that racial minorities deserve to be oppressed because they feel that their population is more numerous than the minority groups. The deliberate destruction of a group of people confirms that racism is an active, negative, and destructive act.

The bold concepts, mostly derived from the focalisasi of the Child in the form of a question and will be answered by his father. This reaffirms the title of his essay, Le Racisme Expliquée À Ma Fille. The "fille" in the title symbolizes all young people born and raised in France, both of immigrant descent and non-immigrant descendants. They all need to be instilled in concepts of racism so that when they grow up, they won't become racist.

The above explanation shows us that Ben Jelloun mentions several social events related to murder/death on the basis of racism. This suggests that racism has a destructive impact on people's social lives. With racism, a community can easily injure or even kill another group that is considered inferior.
Borstelmann defines Apartheid as strong segregation that makes the separation between two groups easier. ${ }^{17}$ Ben Jelloun stated the same thing that Apartheid was a separation that was carried out in South Africa. Around 1930, South Africa adopted a policy of Apartheid to separate whites and blacks. This shows that acts of racism have been around for a long time. The use of the word politics, which is always associated with the word Apartheid, shows government interference in this matter. This reaffirms the previous statement that the government also plays an important role in terms of racism. Apartheid can be characterized by the presence of a white authoritarian political culture, which emphasizes that South Africa is dominated socially, politically, and economically by minorities in the country. ${ }^{18}$ Based on this social strata system, white citizens have the highest status, followed by Asians, people of color, and then the last is black people. Apartheid was also practiced in South African by their government against the majority of its population. Apartheid in South Africa was legally abolished in 1991, but the root of discrimination still continues. $^{19}$

17 Borstelmann Thomas, Apartheid's Reluctant Uncle: The United States and South Africa in the Early Cold War (Oxford: Oxford University Press, 1993), 87.

${ }^{18}$ Alan Mayne, From Politics Past to Politics Future: An Integrated Analysis of Current and Emergent Paradigms, First Edition (Westport, Conn: Praeger, 1999), 52.

19 Farhad Malekian, Principles of Islamic International Criminal Law: A Comparative Search (Leiden: Brill, 2015). 
Foreigners rule others outside their territory for their benefit. They sought to benefit from the people and natural resources of the colonized country. ${ }^{20}$ White people look down on black people by thinking that they are people of no value and deserve to be persecuted. White people always think of themselves as better than the black race because they believe their country of origin is better and more modern than a country dominated by black people. Black people have always been seen as rude and inhuman. They are considered a backward and uncivilized race. This thought is what often comes to the head of the white race.

Grenouilleau and Ben Jelloun both argue that when someone is enslaved, they have a master who has both their body and soul. ${ }^{21}$ A slave will not be free for his life; he will live under the rules of his master and cannot disobey. Slaves can be likened to an item that is bought or rented by someone to become his own. Like goods, slaves are considered inanimate objects, not living things. Slaves are often not considered human because the master feels that he has bought/rented the slave and feels that he can do anything to the slave, even if it hurts the slave.

The next word that will be discussed is Ghetto. Tom Slater distinguishes

20 Lorenzo Veracini, "Settler Colonialism and Decolonisation," Borderlans E-Journal 6, no. 2 (2007): 1-11.

21 Samuel Lempereur, "Olivier Pétré-Grenouilleau, Qu'est-ce que l'esclavage? Une histoire globale," L'Homme. Revue française d'anthropologie, no. 225 (March 15, 2018): 204-7. ghettos from other areas with three characteristics. $^{22}$ The first is ethno-racial control by external authorities. The second is extremely social and spatial segregation. The third ghetto becomes a permanent area. The word ghetto comes from the Jewish area of Venice, Campo del Ghetto.

The downfall of the communal ghetto has been followed by government policies of urban abandonment pursued across the gamut of jobs, healthcare, education, housing, and health at multiple scales - federal, state, and local - and the correlative breakdown of public services in the urban center.

The following word that will be discussed is Genocide. The Genocide is an act to destroy people, usually an ethnic, nationality, racial, or religious group in whole or in part. ${ }^{23}$ Genocide has been around for a long time, The the Jews were victims of genocide by the Nazis in the days of Hitler. This reiterates that the orders of a leader are inevitable and must be carried out. In other words, whoever is in power in a country will influence the activities in that country. A leader of a country who has the heart to spend a certain group just because it is different from them will make the people of that country think the same, that anyone different must be ostracized or even destroyed. This thought is racist because

\footnotetext{
22 Tom Slater, "Ghettos," in The International Encyclopedia of Human Geography, ed. A. Kobayashi, 2nd ed. (London: Elsevier, 2020), 49299.

${ }^{23}$ William Schabas, Genocide in International Law: The Crimes of Crimes (Cambridge: Cambridge University Press, 2000), 25.
} 
of the assumption that a group that is different or considered inferior should be destroyed.

Genocide crimes are often correlated with crimes against humanity, but genocide crimes are distinct from crimes against humans when examined closely. Then genocide can be eliminated partly or entirely, while atrocities against humanity have no other restrictions or requirements. ${ }^{24}$

The term 'genocide' is used by Raphael Lemkin in 1944 in his book, Axis Rule in Occupied Europe. The expression 'genocide' was coined by Lemkin by combining two words: genos, which means ethnicity, country, or tribe in ancient Greek, and caedere, which means to kill in Latin. Winston Churchill called Genocide 'the crime without a name.' The definition of genocide in the 1948 Genocide Convention, is defined as an act to destroy all or part of a nation, caste, ethnicity, or religion.

Genocide happens as a result of racial wars marked by social distance and injustice. Where the adversaries lack cultural similarities, proximity, interdependence, and other aspects of social closeness and where the aggressors have greater authority, military strength, and other forms of status than the hostages, it is more probable. ${ }^{25}$

\footnotetext{
24 Hetty Hassanah, "Kejahatan Genosida dalam Ketentuan Hukum Nasional sebagai Kejahatan Tradisional," Maleo Law Journal 1, no. 2 (2017): 217-35; I Wayan Parthiana, Hukum Pidana Internasional (Bandung: Yrama Widya, 2003), 33.

25 Bradley Campbell, "Genocide as Predation," International Journal of Law, Crime and Justice 43,
}

Thus, awareness of what racism is and counter-racism is very important. There is a contrast here about the severity of the events of human extermination that are used as a conversation, with the public, namely a 10-year-old child. This reaffirms that in Ben Jelloun's view, education on racism should be delivered as early as possible.

\section{Conclusion}

Through his exposure of narrative strategies, Ben Jelloun chose father and daughter figures to make them easier for anyone who read this essay to understand. Children are symbols of the family that must be properly educated and trained. In the passage, it is also stated that according to Ben Jelloun, education is one way of combating racism. For a child not to become a racist, they must be instilled in education about racism as early as possible because education can determine the way a child views a case in their surroundings. Home education is essential in developing a child's mindset because the child will surely imitate what his parents or people are doing nearby. Education in schools is also no less important for a child's knowledge of racism. The focalization technique used shows that the father is the source of information in this essay.

From the analysis of isotope and the field of meaning that has been described, it can be seen that Ben Jelloun stated that racist people are people who are afraid of new things. A racist would regard the

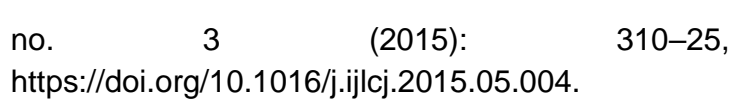


stranger as a threat to him. Ben Jelloun considers that segregation between one group and another is the beginning of racial discrimination. Ben Jelloun also considers that racism is an act that can annihilate or destroy a particular racial group. He also said about race and descent that showed that according to Ben Jelloun, the race is a biological concept, not a social one.

In addition to education, sociocultural aspects also play an important role in the driving or opposing factors of racism. In the essay, mentioned several times words that are closely related to the historical, social aspect. This historical social aspect is proof that racism has been around for a long time. In addition, these aspects prove that racism is a negative and destructive act. It also shows that racism is an active, not passive act.

\section{References}

Campbell, Bradley. "Genocide as Predation." International Journal of Law, Crime and Justice 43, no. 3 (2015): 310-25. https://doi.org/10.1016/j.ijlcj.2015.05 .004 .

Déjeux, Jean. Littérature Maghrébine de Langue Française: Introduction Générale et Auteurs. Sherbrooke: Éditions Naaman, 1980.

Gerard, Genette. An Essay in Method. New York: Cornell University, 1980.

Hassanah, Hetty. "Kejahatan Genosida dalam Ketentuan Hukum Nasional sebagai Kejahatan Tradisional." Maleo Law Journal 1, no. 2 (2017): 217-35.

Jelloun, Tahar Ben. Le Racisme Expliqué à ma Fille. Paris: Editions du Seuil, 2018.
Johnson, Paul. A History of the Jews. New York: Harper Perennial, 1988. https://www.cambridge.org/core/jour nals/language-

teaching/article/abs/influence-ofbilingualism-on-third-languageacquisition-focus-onmultilingualism/EF22C832FD4EFEF D835DB6B11DB5CDD4.

Lempereur, Samuel. "Olivier PétréGrenouilleau, Qu'est-ce que l'esclavage? Une Histoire Globale." L'Homme. Revue Française d'Anthropologie, no. 225 (2018): 204-7.

Malekian, Farhad. Principles of Islamic International Criminal Law: $A$ Comparative Search. Leiden: Brill, 2015.

Martasudjita, E. Pelayanan yang Murah Hati. Yogyakarta: Kanisius, 2003.

Mayne, Alan. From Politics Past to Politics Future: An Integrated Analysis of Current and Emergent Paradigms. First Edition. Westport, Conn: Praeger, 1999.

Nathan, Julie. "Report on Antisemitism in Australia 2019." Edgecliff: Executive Council of Australian Jewry, 2019.

Parthiana, I Wayan. Hukum Pidana Internasional. Bandung: Yrama Widya, 2003.

Redouane, Najib. "La Littérature Maghrébine d'Expression Française au Carrefour des Cultures et des Langues." The French Review 72, no. 1 (1998): 81-90. https://www.jstor.org/stable/399097.

Schabas, William. Genocide in International Law: The Crimes of Crimes. Cambridge: Cambridge University Press, 2000.

Slater, Tom. "Ghettos." In The International Encyclopedia of Human Geography, edited by A. Kobayashi, 2nd ed. London: Elsevier, 2020. 
Stam, Robert. New Vocabularies in Film Semiotics. London: Routledge, 1992.

Syamsuddin, Oom Rohmah. "Hibriditas dalam Permasalahan Imigran Maghribi di Prancis dan Penyajiannya dalam Les Raisins de Galère dan Les Yeux Baissès Karya Tahar Ben Jelloun." Unpublished Doctoral Dissertation, Universitas Indonesia, 2014.

Syarief, Ahmad. "Rasisme terhadap Anak Muda dalam Lagu Ma Couleur." Minithesis, Universitas Indonesia, 2014.

Thomas, Borstelmann. Apartheid's Reluctant Uncle: The United States and South Africa in the Early Cold War. Oxford: Oxford University Press, 1993.
Veracini, Lorenzo. "Settler Colonialism and Decolonisation." Borderlans EJournal 6, no. 2 (2007): 1-11.

Wirawan, Yoga Eka. "Konstruksi Identitas Budaya Tokoh dalam Cerpen Le Père Noël N'est Pas Musulman Karya Tahar Ben Jelloun." Minithesis, Universitas Indonesia, 2018.

Younssi, Anouar El. "An Exoticized World Literature: Ben Jelloun at the Two Shores of the Mediterranean." Alif: Journal of Comparative Poetics 34 (2014): 225-50. 